\title{
ERRATA
}

\section{Die-Away Kinetics of Aerosolized Bacteria from Sprinkler Application of Wastewater}

Division of Human Environmental Sciences, School of Applied Science and Technology, The Hebrew University, Jerusalem, Israel

BENJAMIN TELTSCH, HILLEL I. SHUVAL, AND JACOB TADMOR

Volume 39, number 6, page 1193 , column 1, paragraph 4, line 16: " $4.7 \pm 3 \times 10^{3}$ bacteria per cpm" should read " $4.7 \times 10^{3} \pm 3 \times 10^{3}$ bacteria per cpm."

Page 1193, column 1, line 3 from bottom: " 26 to $11,357 \mathrm{cpm} / \mathrm{s}$ " should read " 26 to $11,357 \mathrm{cpm}$."

Page 1193, column 2, paragraph 3, line 4: “ $(1-R)=100$ " should read " $(1-R) \times 100$."

\section{Acetate as Sole Carbon and Energy Source for Growth of Methanosarcina Strain 227}

\author{
MICHAEL R. SMITH AND ROBERT A. MAH
}

Division of Environmental and Nutritional Sciences, School of Public Health, University of California, Los Angeles, California 90024

Volume 39, number 2, page 995, Table 1, column 4: The values for $q_{\mathrm{CH}_{4}}$ should read $0.139,0.203$, $0.125,0.163,0.141,0.172,0.125$.

Page 996, Table 2, column 4: The values for $q_{\mathrm{CH}_{4}}$ should read $0.140,0.194,0.246,0.215,0.161$.

Page 996, column 1, line 8: The sentence "Similar values of $q_{\mathrm{CH}_{4}}$ were obtained regardless of whether the growth substrate was acetate or methanol" should be deleted.

Page 996, column 2, paragraph 2, lines 23-26: A line was dropped in the final printing. It should read "Moreover, the relative specific activity of $\mathrm{CH}_{4}$ or $\mathrm{CO}_{2}$ produced compared with that of the added acetate was independent of the presence of YE in the medium." 